\title{
THE SERPENT BEGUILED ME AND I DID EAT* THE CONSTITUTIONAL STATUS OF THE ENTRAPMENT DEFENSE
}

PoLICE participation in some aspect of a crime is a common method of law enforcement. Decoy letters are sent to trap postal thieves; officers dress up as drunks and wait to be rolled; plainclothesmen resist homosexual advances only after the suspect has done enough to allow the police to obtain a conviction. So far, none of these methods has been subjected to judicial supervision. ${ }^{1}$ The courts do intervene, however, when the police actively initiate or solicit ${ }^{2}$ a crime in order to prosecute. The most obvious manifestation of such intervention is the judicially created doctrine that certain methods of police solicitation constitute entrapment, which serves as a complete defense against conviction for the solicited crime.

*Judge Parker, writing in Sorrells v. United States, 57 F.2d 973, 976 (4th Cir. 1932). [The defendant's allegation of entrapment,] as was well said in Board of Com'rs of Excise of Onundaga County v. Backus, 29 How. Prac. (N.Y.) 33, "Would be but the repetition of the plea as ancient as the world, and first interposed in Paradise: 'The serpent beguiled me and I did eat.' That defense was overruled by the great Lawgiver and whatever estimate we may form, or whatever judgment pass upon the character or conduct of the tempter, this plea has never since availed to shicld crime or give indemnity to the culprit, and it is safe to say that under any code of civilized, not to say christian ethics, it never will."

Judge Parker was reversed by the Supreme Court, 287 U.S. 435 (1932).

1. See discussion in both the majority and concurring opinions in Sorrells v. United States, 287 U.S. 435, 441-42, 453 (1932).

2. In this, as in other areas of the law, it is often difficult to distinguish between activity and purposeful inactivity. See, e.g., this recent news item:

LOS ANGELES (AP) - The police say a pickpocket tried to dip into a pocket belonging to a lawman and got caught.

"I was sure they were pickpockets even before I got on the bus," said Oscar O'Lear, a member of the Police Department pickpocket detail. Mr. O'Lear, who was Christmas shopping off-duty, sat next to one of the men.

Almost immediately he felt a tugging at the wallet in his pocket, he said later. After the man had invested 15 minutes of patient labor to get the wallet, Mr. O'Lcar put the finger on him and his "partner."

N.Y. Times, Monday, December 21, 1964, p. 21, col. 3.

This Note will not be concerned with distinguishing between solicitation and its near equivalents, except to suggest that the test ought not to depend exclusively on "Year Book distinctions between feasance and nonfeasance," Lambert v. California, 355 U.S. 225, 231 (1957) (Frankfurter, J., dissenting), but also on the presence or absence of the characteristic dangers of solicitation. These dangers are maximized when the police select a particular individual and offer him a criminal opportunity which might not otherwise have been available. Officer O'Lear's conduct probably should be considered solicitation if the passively encouraged the attempt. 
Now in its fiftieth year, the entrapment defense has been widely criticized as a failure. ${ }^{3}$ Its objective - preventing the police from turning innocent men into criminals - is almost universally accepted. ${ }^{*}$ But this objective has been frustrated by ambiguous standards, unresponsive appellate courts and prejudicial trial procedures. This Note will argue that the basic objective of the entrapment defense is dictated by the Constitution, and that the current formulation of the defense falls so short of realizing this purpose as to be unconstitutional. Consistent adherence to this constitutional imperative would produce an entrapment defense, binding on the states as well as the federal government, ${ }^{5}$ which is broader in scope and sharper in definition than the current doctrine.

The leading federal case on entrapment is Sorrells $v$. United States. The issue in Sorrells was whether the conduct of Martin, a prohibition agent, justified submitting the issue of entrapment to the jury. Martin, an old war buddy of the defendant, paid him what turned out to be a business call. Martin suggested that Sorrells sell him a half gallon of liquor; Sorrells replied that "he did not fool with whiskey." Martin pressed the point and, one hour and several requests later, Sorrells produced the liquor. Martin then made the arrest which was the purpose of his visit. There was no evidence that the defendant had ever violated the liquor laws prior to the solicitation. The trial court refused to give instructions on entrapment and was upheld by the Fourth Circuit. 8 The circuit court affirmed the principle that "the purpose

3. See, e.g., Mikell, The Doctrine of Entrapment in the Federal Courls, 90 U. PA. L. Rev. 245 (1947); Donnelly, Judicial Control of Informants, Spies, Stool Pigcons ond Agents Provocateurs, 60 YALE L.J. 1091, 1098-1115 (1951); Note, Entrapment, 73 HARs. L. REv. 1333 (1960). In 1933 Judge Learned Hand approached the entrapment doetrine with somber resignation:

The decisions are plentiful, but the judges generally content themselves with deciding the case on the evidence before them; we have been unable to extract from them any definite doctrine, and it seems unprofitable once more mercly to catalogue the citations.

United States v. Becker, 62 F.2d 1007, 1008 (2d Cir. 1933). By 1957 four Supreme Court Justices were willing to characterize the current entrapment doctrines as "gropingly ... express[ing] the feeling of outrage at conduct of law enforcers . . . but without the formulated basis in reason that is the first duty of courts to construct ...." Sherman v. United States, 356 U.S. 369, 378 (1958) (concurring opinion).

4. The entrapment defense has been accepted in 43 states, rejected in only two New York and Tennessee. Comment, The Docirine of Entrapment and Its Application is Texas, 9 Sw. L.J. 456, 465 (1955). But only rarely has it been successiully involed by a defendant in state courts. Donnelly, supra note 3 , at 1106 n.42.

5. Throughout this Note, "due process" will be used to refer to the due process clauses of the fifth and fourteenth amendments. Fourteenth amendment cases are used to demonstrate the due process dimensions of the entrapment defense as applied to the states. The requirements placed on the federal government by the due process clause of the fifth amendment are certainly no less severe. See Hurd v. Hodge, 334 U.S. 24, 35-36 (1948); Bolling v. Sharpe, 347 U.S. 497, 499-500 (1954).

6. 287 U.S. 435, reversing 57 F.2d 973 (4th Cir. 1932).

7. Id. at $439-41$.

8. 57 F.2d 973. 
of solicitation is not to make criminals, but to detect those who are engaged in criminal practices." But it rejected the entrapment defense on the theory that even improper solicitation cannot excuse a violation of a criminal statute. ${ }^{10}$ The Supreme Court accepted the Fourth Circuit's view of the proper purposes of solicitation and attributed them to Congress as well: "Congress could not have intended that its statutes were to be enforced by tempting innocent persons into violations." 11 As a result of this statutory construction, the Court held that acquittal was the remedy for improper solicitation. Thus the failure to submit the issue of entrapment to the jury required a new trial.

While condemning improper solicitation, the Court did not specify which aspects of the police conduct in Sorrells were improper. The objective of limiting solicitation to the detection of crime might have been sought by imposing any or all of three limitations on police conduct. Violations of all three were involved in Sorrells, but the opinion does not make clear whether violation of any one would give rise to the entrapment defense. An initial limitation on police conduct would be to require that reasonable grounds be shown in advance for believing that the solicitee is engaged in criminal activity. As search and seizure law recognizes, a restriction on invasion of privacy will be totally ineffective if the police can use information obtained from the invasion to justify their conduct. ${ }^{12} \mathrm{~A}$ second restriction, which would limit the permissible targets of solicitation, would allow conviction for a solicited offense only if it appears reasonably certain that the defendant would have committed a similar offense in the absence of solicitation. This limitation would prevent solicitation from being used to create crime; in particular, it would protect the man who has "gone straight" from being lured back into crime. ${ }^{13}$ Third, police methods of solicitation might be controlled by prohibiting the use of coercion. Coercing a suspect into committing a crime would seem a fortiori to be inconsistent with the postulated congressional intent. Coercion, moreover, lessens the probability that the defendant would have committed a similar crime without the solicitation.

While the Sorrells opinion does not explicitly adopt any of these standards, it places heavy emphasis on the second limitation. The Court stressed the absence of proof that Sorrells was engaged in a course of criminal conduct, and it implied that conviction is permissible only if the solicitee had a "criminal

9. Id. at 975.

10. "It is time to get back to fundamentals. The law is supreme. No man may violate it with impunity." Id. at 978.

11. Summary of Sorrells in Sherman v. United States, 356 U.S. 369, 372 (1957).

12. See Johnson v. United States, 333 U.S. 10, 16-17 (1948); Brinegar v. United States, 338 U.S. 160, 188 (1949) (Jackson, J., dissenting).

13. As Mr. Justice Frankfurter observed, Past crimes do not forever outlaw the criminal and open him to police practices, aimed at securing his repeated conviction, from which the ordinary citizen is protected. The whole ameliorative hopes of modern penology and prison administration strongly counsel against such a view.

Sherman v. United States, 356 U.S. 369, 383 (1957) (concurring opinion). 
predisposition and design."14 In other words, solicitation is justified only when it provides the defendant with a victim for a crime he previously had intended to commit. State and lower federal courts, however, have concentrated almost exclusively on the implied limitation against coercion by reducing the limitation regarding permissible targets to one which can never be violated in the absence of coercion. In their view, "ready complaisance" with a solicitation indicates both that coercion was absent and that the defendant was an appropriate target for solicitation. ${ }^{15}$ Under this formulation of the entrapment defense, the police may solicit anyone in the hope that the solicitation will provide its own justification.

Any test, however, which allows unlimited solicitation and conviction of all those who succumb is inconsistent with the Constitution. The due process clause permits deprivation of liberty only in order to accomplish a legitimate objective of society. ${ }^{16}$. Unlimited ability to solicit satisfies no such interest. In Sherman v. United States, the other major Supreme Court decision on entrapment, the concurring justices observed:

The power of government is abused and directed to an end for which it was not constituted when employed to promote rather than defect crime

14. According to Sorrells,

the controlling question [is] whether the defendant is a person otherwise innocent whom the Government is seeking to punish for an alleged offense which is the product of the creative activity of its own officials. [In answering this question] [t] he predisposition and criminal design of the defendant are relevant.

287 U.S. 435, 451. The phrase "alleged offense" is ambiguous. If it refers to the particular offense for which the defendant is tried, then all solicitation runs afoul of the entrapment doctrine. The solicited offense is always the product of the creative activity of government officials, since it is planned and invited by them. But the entrapment defense is not nearly this broad. It assumes proper dimensions if the "alleged offense" is taken to mean an offense except for the fact of a different victim.

15. See, e.g., Kivette v. United States, 230 F.2d 749 (5th Cir. 1956); United States v. Wallace, 269 F.2d 394 (3d Cir. 1959). Two opinions of Learned Hand recognize that the "ready complaisance" of the defendant is not necessarily related to a pre-existing course of criminal conduct, while holding that complaisance alone can serve as a posi hoc justification for solicitation. United States v. Becker, 62 F.2d 1007, 1008 (2d Cir. 1933); United States v. Sherman, 200 F.2d 880, 882 (2d Cir. 1952) (an earlier stage of the prosecution involved in the Shernan case) The Supreme Court opinion reversing Sherman's sccond conviction does not repudiate the "ready complaisance" doctrine, but suggests that complaisance must be proved by some evidence of intent, design or past conduct. 356 U.S. 369, 375 (1955).

16. See West Virginia State Bd. of Educ. v. Barnette, 319 U.S. 624,636 (1943). The substantive due process cases also establish this proposition; the Court's more liberal conception of a legitimate state interest in the sphere of economic legislation does not alter the prohibition against arbitrary legislative deprivation of liberty. Compare Adkins v. Children's Hosp., 261 U.S. 525, 546 (1923) (". . . the exercise of legislative authority to abridge [freedom of contract] can be justified only by the existence of exceptional circumstances."), with West Coast Hotel Co. v. Parrish, 300 U.S. 379, 391 (1937) ("regulation which is reasonable in relation to its subject and is adopted in the interests of the community is due process"). 
and to bring about the downfall of those who, left to themselves, might well have obeyed the law. ${ }^{17}$

Of course, it can be argued that the government has an interest in punishing all those who violate its laws, regardless of the way in which the violation came about. But this notion of the interest involved depends upon overlooking half of a single scheme; the government's interest cannot be confined to the stage of punishment and ignored at the stage of violation. ${ }^{18}$ Solicitation for the sake of obtaining convictions transforms a law to promote the general welfare into a technique designed to foster disobedience in order to punish.

It has also been argued that a defendant who violates the law at the instigation of a police officer is morally as guilty as one who is induced by a private party to act criminally. ${ }^{19}$ But there is no state interest in punishing a defendant because of his moral guilt unless he has harmed another individual or society at large. ${ }^{20}$ Since a solicited offense is contrived and controlled by the police, it is difficult to see how it could be harmful to society. If, however, stuccessful solicitation does produce harmful conduct, then the practice itself could hardly serve a legitimate state goal, for the police themselves would have promoted the injurious act. Even under the rationale of moral guilt, therefore, a conviction based on unlinited solicitation would be prohibited by the due process clause.

Unlimited solicitation would also violate the act requirement and its tu1derlying policies. Some act ${ }^{21}$ attributable to the defendant is one of the traditional and universal elements of criminal liability and would seem to be an essential feature of due process. ${ }^{22}$ This requirement is not merely an in-

17. Sherman v. United States, 356 U.S. 369, 384 (1955) (concurring opinion) (emphasis added).

18. Olmstead v. United States, 277 U.S. 438, 470 (1928) (Holmes, J., dissenting). Thus, in search and seizure cases, the constitutional wrong involves both the initial police misconduct and the validation of such misconduct by a court which accepts illegally scizcd evidence. See Mapp v. Ohio, 367 U.S. 643, 655-56 (1961). Similarly, the cvil of entrapment comprises both approaching an innocent man to lure him into crime, and punishing him once he has succumbed. Sce Sorrells v. United States, 287 U.S. 435, 448-49 (1932).

19. See, e.g., Sorrells v. United States, 57 F.2d 972, 975 (4th Cir.), revid, 287 U.S. 435 (1932); Mikell, supra note 3 , at 264.

20. Thus, laws which prohibit private consensual behavior are justificd by their supporters on the theory that the prohibited behavior hurts society, not simply that it is immoral. See, e.g., Commonwealth v. Allison, 227 Mass. 57, 62, 116 N.E. 275, 276 (1917), referring to anti-contraceptive statutes. See also Report of the British Roman Catholic Advisory Committee on Prostitution and Homosexual Offenses and the Existing Lazu, reprinted in Donneily, Goldstein \& Schwartz, Criminal LAw 140-41 (1962).

21. An act may be an omission of a specifically prescribed legal duty. The essential requirement is that criminal liability be based on conduct which is subject to voluntary control.

22. In Robinson v. California, 370 U.S. 660 (1962), the Supreme Court held that a state could not, consistently with the due process clause, punish a man for being a narcotics addict. The Court noted that the defendant could be punished for the act of using narcotics. 
heritance from the retributive theory of justice; basic considerations of political power are involved. The act requirement limits the power of police and prosecutors by allowing them to select defendants for punishment only from among those whose criminal potential has ripened into overt acts. If an act were not required, police and prosecutor could select as defendants anyone - or everyone - with criminal potential. Very few of us are not within this class of imperfect human beings.23 Indeed, unlimited power to prosecute and to punish is a defining characteristic of absolutism - from medieval tyranny to the modern police state.24 Unlimited power to solicit illegal acts would circumvent the act requirement since the police would have it in their power to turn almost anyone into a defendant by selecting a means designed to exploit his particular weakness. Even if the act requirement is not itself an element of due process, the limitation on state power which it is designed to accomplish would seem to be fundamental to the concept of "ordered liberty."25 Thus the due process clause suggests that the police must select targets for solicitation on the basis of some criterion which accomplishes a legitimate state purpose and which imposes some limit on the state's ability to select defendants.

It might be thought that allowing solicitation of the "dangerous" - people who are thought especially likely to commit a crime - would be an appropriate limitation on the targets of solicitation. Such a limitation would establish a standard falling between untrammelled power to solicit and power to solicit only those engaged in a course of criminal conduct or those having an immediate disposition to commit an offense - the test implicit in Sorrells. But any such "dangerousness" tèst must be rejected for the same reasons which led to the determination that unlimited solicitation would be unconstitutional. Dangerousness, if it is not to be proved by past conduct or criminal design, is inherently incapable of any definition which would prevent it from becoming unlimited power to solicit. A strict test for dangerousness might demand a showing of high probability that the defendant would commit a similar crime at some time in the future. But since most people are likely to commit some crime - be it a traffic violation, adultery or loitering in a public place - during their remaining life span, the test would still be tantamount to an unlimited power to select solicitation targets. An even more restrictive test could be established by considering people dangerous only if they are likely to commit a crime in the near future. But if proximity to crime is not to be determined by continuing criminal conduct or an immediate criminal disposition, the trier of fact would be left without firm standards on which

23. See Freud, "Criminals From A Sense of Guilt," 14 Cosrplete Psychologicar WORKS OF StGMUNd FREUD 332-33 (1957).

24. See, e.g., If 37 \& 43, The Record \& Process of the Deposition of Richard II, III Rotuli Parliamentortum 416, 420 (3d ed. 1832); Shirer, The Rise and Fall of tie Third Reich (1960); Koestler, Darkness at Noon (1941).

25. See Palko v. Connecticut, 302 U.S. 319, 325 (1938). 
to base a highly specific prediction of human behavior. ${ }^{20}$ Of course, the prosecutor might introduce psychiatric testimony. But psychiatry does not claim the ability to make tolerably accurate predictions of such behavior.27 Moreover, the law has not taken the far-reaching step of basing criminal liability solely on psychiatric projection, and there would seem to be no reason to introduce this procedure into the context of solicitation. ${ }^{28}$ Finally, allowing the state to entice dangerous people into crime is destructive of the act requirement, because it allows the state to substitute a contrived act for a spontaneous offense. Convicting a man simply on the basis that he is likely to harm society in the future is offensive to Anglo-American legal practice 20 and, in all likelihood, to the Constitution. ${ }^{30}$

The constitutional standards - the act requirement and the advancement of a legitimate goal of the state ${ }^{31}$ - would, however, be satisfied by a test

26. Bad acts and reputation testimony might be introduced in an effort to prove that the defendant would have committed a similar crime in the near future. But the result of considering such neighborhood gossip to be probative would be to allow solicitation of anyone whose life has not been blameless.

27. See Goldstein \& Katz, Dangerousuess and Mental Illness: Some Observations on the Decision to Release Persons Acquitted by Reason of Insanity, 70 YALE L.J. 225 (1960).

28. Psychiatric projection of dangerousness has been used in determining whether defendants who have been acquitted solely by reason of insanity should be released from a mental hospital. See D.C. Code ANv. \$ 24-301 (Supp. VIII, 1960). In these cases, the state's right to detain the defendant follows from his unprompted commission of a forbidden act. A decision that he should not be released is like a decision denying parole, and can be based on less reliable evidence than is required for a criminal conviction. Sce generally Goldstein \& Katz, supra note 27.

29. See Hart, Legal Responsibility and Excuses, in DeterminisM ANo FREedoM in THE AGE OF MODERN SCIENCE 109-12 (Hook ed. 1958).

30. Cf. the opinion of Mr. Justice Jackson, as Circuit Justice in Williamson v. United States, 184 F.2d 280 (2d Cir. 1950), granting bail to convicted communists who were awaiting decision on a petition for certiorari:

If I assume that defendants are disposed to commit every opportune disloyal act helpful to Communist countries, it is still difficult to reconcile with traditional American law the jailing of persons by the courts because of anticipated but as yet uncommitted crimes. Imprisonment to protect society from predicted but unconstummated offenses is so unprecedented and so fraught with danger of excesses and injustice that I am loath to resort to it, even as a discretionary judicial technique to supplement conviction of such offenses as those of which the defendants stand convicted.

Id. at 282-83.

The same point was made by a federal district court in allowing the discharge of a mental patient who was evaluated by the hospital as "potentially dangerous to others and if released is likely to repeat his pattern of criminal behavior, and might commit homicide." In the Matter of Williams, 157 F. Supp. 871, 876 (D.D.C. 1958).

In Robinson v. California, 370 U.S. 660 (1962), discussed in note 22 supra, narcotics addicts posed as high a likelihood of committing future crimes (possession, use, sale) as is ever likely to be found. Yet a conviction based on addiction alone, without proof of a past act, was unconstitutional.

31. The constitutional status of the entrapment defense has been dealt with only in a bizarre opinion by the Seventh Circuit and in two contradictory opinions by identical Ninth 
which adhered to the limitation on target selection implicit in Sorrells: the solicitee must have been engaged in a course of criminal conduct or must have been on the verge of a crime. Such a test would operate to confine solicitation to the obviously legitimate purpose of detecting rather than crenting crime. And the criminal conduct or design test is intended to insure that the solicited offense is only a substitute for a criminal act which the defendant would have committed without the solicitation. Thus the power of the state to select defendants would be subject to essentially the same limitation as is imposed by the act requirement.

The two auxiliary limitations on police solicitation suggested by the facts in Sorrells - the requirement that the police have probable cause prior to solicitation and the prohibition against coercion - seem also to be of constitu-

Circuit panels dealing with the same case. In United States ex rel. Frall v. Illinois, 329 F.2d 354 (7th Cir. 1964), the court intimated that the Constitution prohibits the practice of entrapment, but held that it does not protect an individual victim - at least in a state which takes generally effective action against the practice. The court observed that

When the several states have consistently discharged their responsibility to socicty in giving full recognition of their constitutional obligation to prevent the prostitution of state judicial power through lawless enforcement of the criminal law, the need for federal intervention is not apparent.

Id. at 359-60 (emphasis added).

This view of the fourteenth amendment owes little to its language. The amendment purports to protect the liberty of persons, not the chastity of power. Denial of due process of law refers primarily to exceptional deviation from the regular course of judicial proceedings; the rarity of the abuse only emphasizes the deviation. An individual defendant whose treatment by a state "shocks the conscience" cannot be barred from federal relief simply because other defendants are more fairly treated or other states are better behaved. The court in Hall relies on Mapp v. Ohio, 267 U.S. 643 (1961), to support the view that the due process clause is inoperative in the absence of widespread state misconduct. But the Mapp opinion made clear that a single instance of state misconduct is sufficient to invoke the Constitution:

[N]othing could be more certain than that when a coerced confession is involved, "the relevant rules of evidence" are overridden without regard to "the incidence of such conduct by the police," slight or frequent. Why should not the same rule apply

to what is tantamount to coerced testimony by way of unconstitutional seizure...." Id. at 656 .

In view of its novel conception of the fourteenth amendment and its miscitation of Mapp, the Hall case cannot be taken to settle the constitutional status of the entrapment defense.

In Banks 8. United States, 249 F.2d 672 (9th Cir. 1957), the court held that a claim of entrapment, if valid, would establish a violation of the due process clause of the fifth amendment. After a district court hearing on the merits, the same pand held per curiam that the petitioner had raised no constitutional question by his allegation that the trial court's instruction on entrapment was insufficient. Banks v. United States, 258 F.2d 318 (9th Cir.), cert. denied, 358 U.S. 886 (1958). One case has interpreted the second Bants decision as repudiating the first. Simmons v. United States, 302 F.2d 71, 78 (3d Cir. 1962). But a Ninth Circuit decision has cited the second Banks case for the more limited proposition that errors in instructions must be corrected on appeal and cannot be reached in a federal post-conviction relief proceeding. Cambiano v. United States, 295 F.2d 13, 14 (9th Cir. 1961), cert. destied, 368 U.S. 999 (1962). 
tional status. Since due process limits solicitation to the purpose of crime detection, constitutional restrictions upon methods of gathering evidence provide persuasive analogies. Indeed, the Supreme Court suggested these analogies in Sherman, where it equated entrapment with the unlawful search or the coerced confession..$^{32}$ Because permissible solicitation is functionally equivalent to police efforts to obtain confessions, the constitutional protection against coercion should apply. The basic objectives of solicitation and interrogation are identical - to induce the defendant to supply evidence of his guilt. And the methods used share a crucial feature; in each case the police do not merely collect extrinsic evidence, but actively entice the defendant to incriminate himself. The only meaningful difference is that in the case of solicitation the police disguise their identity ${ }^{33}$ and elicit non-verbal ${ }^{34}$ conduct which the defendant does not realize will be used against him.

Thus a crucial question in all solicitation cases should be whether the police conduct constituted "coercion," as that term has been defined in the coerced confession cases. The Supreme Court has recently observed in Malloy $v$. Hogan $^{35}$ that the constitutional test of a confession

.... is whether the confession was "free and voluntary: that is, [it] must not be extracted by any sort of threats or violence, nor obtained by any direct or implied promises, however slight, nor by the exertion of any improper influence ..."

The Court added that the fourteenth amendment also "prohibits the States from inducing a person to confess through 'sympathy falsely aroused,' . . . . [It secures] the right of a person to remain silent unless he chooses to speak in the unfettered exercise of his own will."37

32. Sherman v. United States, 356 U.S. 369, 372 (1958).

33. Coercion should not be considered less unconstitutional when it is applied by an undercover agent. In Massiah v. United States, 377 U.S. 201 (1964), the Supreme Court held that the defendant's right to counsel during interrogation - a right granted him largely in order to protect against coercion - applied to interrogations conducted by an informer. The Court observed:

It is true that in the Spano case the defendant was interrogated in at police station, while here the damaging testimony was elicited from the defendant without his knowledge while he was free on bail. But, as Judge Hays points out in his dissent in the Court of Appeals, "If such a rule is to have any efficacy it must apply to indirect and surreptitious interrogations as well as those conducted in the jailhouse." In this case, Massiah was more seriously imposed upon . . . because he did not even know he was under interrogation by a government agent.

Id. at 206 (emphasis added).

34. Verbal conduct alone is often sufficient to constitute a crime - see, c.g., 21 U.S.C. \& 176(b) (1958) (conspiracy to sell heroin to a juvenile, which carries a possible death penalty). In some cases, solicitation seems to be commonly used to elicit verbal crimes. See Kelly v. United States, 194 F.2d 150 (D.C. Cir. 1952) (reversing a conviction for unlawfully inviting a person to accompany one for a lewd and immoral purpose; here the officers solicited passers-by in a Washington park).

35. 378 U.S. 1 (1964).

36. Id. at 7.

37. Id. at 8 . 
The rationale behind this strict standard is one that allows no distinction between solicitation and interrogation:

[The voluntariness test] reflects recognition that the American system of criminal prosecution is accusatorial, not inquisitorial, and that the Fifth Amendment privilege is its essential mainstay . . . . Governments, state and federal, are thus constitutionally compelled to establish guilt by evidence independently and freely secured, and may not by coercion prove a charge against the accused out of his own mouth..$^{33}$

Similarly, the government should not be allowed to coerce a person into supplying by his conduct the elements of an offense. It is unreasonable to suppose that the Constitution protects a person against confession of an actual crime and not against commission of a staged offense, as if tempting a man to be honest were more reprehensible than tempting him to be wicked.

In applying the coercion doctrine to solicitation, however, the courts should bear in mind the differences between open police interrogation and undercover solicitation. The innately coercive atmosphere of the police station is absent in the latter case; thus the same conduct by an officer may be permissible when he solicits a crime but prohibited when he demands a confession.90 Additionally, the role of money differs in the two cases. A bought confession is presumably one which the defendant would not have made voluntarily. But the exchange of money may be an essential part of the solicitation - for example, when a narcotics agent buys a fix. Unless the offering price is excessive or the defendant peculiarly weak-willed, the defendant should not be allowed to claim that his will was overborne by the offer of the purchase price.

The constitutional prohibition of unreasonable searches and seizures suggests another limitation on permissible solicitation. Like a police search, solicitation involves an intrusion into privacy. The kinds of privacy involved are different - the privacy of one's premises in the first case, the privacy of one's will and disposition in the second case. But certainly the right to be free from official enticement into crime is no less important than the right to be free from physical encroachments aimed at detecting crime. If either right is to be invaded by the government, it must be for a substantial cause. Solicitation should be confined to those reasonably suspected of criminal conduct or design, thus limiting the invasion of privacy inherent in police solicitation to those - people who could constitutionally be tried for a solicited offense. Some ases suggest this restriction on solicitation, but leave enforcement entirely to the

38. Id. at 7-8.

39. For example, a soliciting officer would have to be permitted to assure a skeptieal solicitee that he will tell no one about the transaction. But a police interrogator is probably required to inform the suspect that anything he says may be used against him. See Escobedo v. Illinois, 378 U.S. 478 (1964). 
trial stage.40 This approach, however, fails entirely to protect those who do not succumb, or who cannot constitutionally be convicted, from the invasion of personal integrity that solicitation involves. An independent judgment by a magistrate prior to solicitation would avoid this pitfall. An official British report has recognized the need for safeguarding privacy and has proposed that the police be required to obtain a warrant from a magistrate before soliciting a person to commit an offense. ${ }^{41}$ The fourth amendment would suggest a similar procedure prior to solicitation. ${ }^{42}$

In summary, the Constitution establishes three independent limitations on police conduct; breach of any one giving rise to a valid entrapment defense. The privilege against self-incrimination prohibits the use of coercion in solicitation. Due process forbids the conviction of any person for a solicited offense unless he had been engaged in a course of criminal conduct or had a criminal design. And the prohibition against search and seizure requires the police to have reasonable grounds for suspecting such conduct or design before they engage in solicitation. And by acknowledged operation of the fourteenth amendment, each of these three limitations is applicable to the state, as well as the federal government.

Correlative to the constitutional limitations on police solicitation is the requirement that an effective means be provided for acquitting victims of unconstitutional solicitation. ${ }^{43}$ But so long as the defendant is being tried for the solicited offense rather than for his past conduct or criminal design, the constitutional limitations will be difficult to enforce at the trial. The basic problem is whether or not to let the jury decide whether the defendant was a proper target for solicitation. This issue has divided the Supreme Court

40. See, e.g., Ryles v. United States, 183 F.2d 944 (10th Cir. 1950); C. M. Spring Drug Co. v. United States, 12 F.2d 852 (8th Cir. 1926).

41. Report of the Royai Commisston on Police Powers and Procedure (Cmd. No. 3997) 42 (1929), quoted in Donnelly, Judicial Control of Informants, Spics, Stool Pigeons, and Agent Provocateurs, 60 YALE L.J. 1091, 1114 n.65 (1951).

42. As the Supreme Court observed in Johnson v. United States, 333 U.S. 10 (1948): The point of the Fourth Amendment, which often is not grasped by zealous officers, is not that it denies law enforcement the support of the usual inferences which reasonable men draw from evidence. Its protection consists in requiring that thosc inferences be drawn by a neutral and detached magistrate instead of being judged by the officer engaged in the often competitive business of ferreting out crime. Id. at 13-14.

43. See Jackson v. Denno, 378 U.S. 368 (1964), where the Court found that the New York procedure for determining the admissibility of an allegedly coerced confession did not adequately protect the rights of the accused.

The procedures used in the trial court to arrive at its conclusions on the coercion issue progressively take on added significance as the actual measure of the protection afforded a defendant under the Due Process Clause of the Fourteenth Amendment against the use of involuntary confessions. These procedures must, therefore, be fully adequate to insure a reliable and clear-cut determination of the voluntariness of the confession....

Id. at 391. 
in both of its major entrapment decisions, ${ }^{\text {sh }}$ and each alternative solution has major defects. If the decision is left to the jury, there is a substantial danger that the jury will infer either a course of criminal conduct or a criminal design from the very fact of successful solicitation, thus effectively frustrating the constitutional limitations on solicitation. ${ }^{45}$ One approach to this problem would be to remove the issue of past conduct or design from jury consideration. But this issue seems particularly appropriate for jury decision because it is an essential part of the basis for punishment and because it involves the questions of credibility and motivation. The entrapment defense would seem to be as much a jury question as insanity or self-defense. In addition, taking this issue from the jury might conflict with constitutional guarantees of a jury trial, at least within the federal system. ${ }^{46}$

Conceivably, the issue of permissible solicitation could be decided in the first instance by the judge; if he ruled against the defendant, the same issue would then be submitted to the jury for independent resolution. But a more straightforward and effective method of realizing the basically evidentiary purpose of solicitation would be to give procedural effect to that purpose. The fact of a successful solicitation would not in itself give rise to criminal liability; it would only be relevant as evidence of an independently existing course of criminal conduct. Treating a successful solicitation as evidence of a past crime would eliminate several defects inherent in trials for the solicited offense. First, this procedure would not be subject to the existing tendency to admit highly prejudicial past crimes and reputation testimony which is not strongly probative on the issues of a continuing course of criminal conduct or of an immediate disposition to commit crime. ${ }^{47}$ Rather, liability would only

44. Sherman v. United States, 356 U.S. 369, 385 (Frankfurter, J., concurring); Sorrells ₹. United States, 287 U.S. 435, 457 (Roberts, J., concurring).

45. The New York procedure which was found uneonstitutional in Jackson v. Denno, 378 U.S. 368, involved closely analogous dangers. New York allowed the jury to determine the voluntariness of an allegedly coerced confession. The Supreme Court felt that a jury which found the confession trustworthy would be under pressure to find it roluntary in order to send a guilty man to jail. Alternatively, a jury which found the coniession involuntary would nonetheless have it firmly implanted in its mind. Id. at 388.

46. Trial by jury is guaranteed by the Constitution, both in Art $3, \S 2$ and the sixth amendment, and in many state constitutions. In a federal criminal case, the guarantee is violated when the judge decides one of the essential elements of the crime. United States v. Manuszak, 234 F2d 421 (3d Cir. 1956) ; Carothers v. United States, 161 F.d 718, 722 (5th Cir. 1947).

State constitutional provisions requiring a jury trial in civil cases have been held to require that particular issues be submitted to the jury - e.g., probable cause in a suit for malicious prosecution, Jennings v. Clearwater MIfg. Co., 171 S.C. 498, 172 S.E. 870 (1934), and that the issue of liability as well as damages be open to jury consideration after a verdict has been set aside for excessive damages. In re Opinion of the Justices, 207 MIass. 606, 94 N.E. 846 (1911).

47. See, e.g., United States v. Johnson, 208 F.2d 404, 406 (2d Cir. 1953), cert. deried, 347 U.S. 928 (1954); Carlton v. United States, 198 F.2d 795 (9th Cir. 1952); United States v. Siegel, 16 F.2d 134 (D. Minn. 1926). 
be based on unpunished past conduct; the solicited behavior, if closely related and probative, would be admissible to prove the past crime, and all bad acts testimony other than the fact of successful solicitation would be governed by the usual restrictive rules of evidence. Second, the current tendency to predicate a previous course of criminal conduct as a prerequisite to conviction for a solicited offense, but to infer the previous course from the successful solicitation, would be eliminated. Finally, removing the source of improper inferences would allow recognition of the proper role of the jury.

Using the results of solicitation as evidence of prior crimes would result in one substantive change in the test derived from Sorrells. Criminal design alone could not be a ground for conviction, because it would involve no prior criminal conduct which could be prosecuted with the aid of solicited evidence. This change, however, should not significantly decrease the permissible scope of solicitation, since the police will seldom know of the criminal design of a person who has not previously engaged in a course of criminal conduct, and since it is unlikely that a solicitation warrant could be obtained on the basis of speculation about design alone. If police knowledge is based on more than speculation, it is likely to be derived from acts sufficient to allow conviction for some crime - for example, attempt, conspiracy, criminal solicitation, possession..$^{48}$ Moreover, allowing solicitation of those not engaged in a course of criminal conduct represents a deviation from the act requirement, even if the criminal design test does place equivalent restrictions on state power. No amount of proof of criminal design can guarantee that the defendant would have committed the act without the state's intervention.

The constitutional doctrine suggested by this Note, in addition to establishing the due process status of an entrapment defense, would limit the permissible targets and methods of solicitation to a narrower range than permitted by administration of existing doctrine. The most likely objection to this narrow formulation of permissible solicitation is that it would severely hamper law enforcement. Many have argued that solicitation is necessary to detect crimes of consent, such as narcotics offenses and prostitution. ${ }^{40}$ All the participants in such crimes are subject to criminal liability. Since the immediate victims of the crime are also its perpetrators, they may refrain from reporting it either from fear of prosecution or because they are content to be victimized. Thus society cannot rely on receiving proof of past acts by voluntary disclosure. But this view has not been supported on factual grounds. Criminals of the type described deal with hundreds of customers, not all of whom will be satisfied. Malice, moral reawakening or the desire to be useful to the police may lead many to confess. Threats of prosecution and promises of immunity

48. One purpose of current solicitation practices may be to allow the police to arrest a defendant whom they know to be guilty of an offense for a more serious offense of the same general nature.

49. See, e.g., Mr. Justice Roberts' concurring opinion in Sorrells v. United States, 287 U.S. 435, 453-54 (1932); Note, Entrapment, 73 HaRv. L. REv. 1333, 1338 (1960); Note, Entrapment by Government Officials, 28 CoLun. L. Rev. 1067, 1069 (1928). 
are the standard, and highly effective, means of persuading participants to tell their stories to the police. If prostitutes or narcotics peddlers go unpunished, public apathy or police corruption are as likely explanations as unavailability of evidence. Arguments from practical necessity, unsupported by convincing proof, should not make us less willing to give full effect to constitutional guarantees. In any event, the convenience of questionable police methods is not the ultimate test of their constitutionality. A society which ranks personal integrity above the goal of obtaining convictions need not tolerate coercive or unoccasioned solicitation. 